\title{
Asaccharolytic Black-Pigmented Bacteroides Strains from Soft- Tissue Infections in Cats
}

\author{
DARIA N. LOVE, ${ }^{*}$ R. F. JONES, AND ANNE CALVERLEY \\ Department of Veterinary Pathology, The University of Sydney, New South Wales 2006, Australia
}

\begin{abstract}
Using phenotypic characterization, we found that 17 strains of asaccharolytic pigmented Bacteroides species isolated from soft-tissue infections in cats could be divided into five distinct groups. All of these strains were catalase positive, required vitamin K-hemin for growth, did not grow in bile, and did not exhibit $\alpha$-glucosidase activity. The organisms in groups $\mathrm{A}$ and $\mathrm{E}$ (five strains) did not fluoresce under ultraviolet light at $365 \mathrm{~nm}$ and were indole positive. Group A organisms hemagglutinated sheep erythrocytes, but group E strains did not. The members of both of these groups produced large amounts of phenylacetic acid (group A average, $497 \mu \mathrm{g} / \mathrm{ml}$; group E average, $404 \mu \mathrm{g} / \mathrm{ml}$ ), and both groups showed trypsin-like activity (detected by using $N$-benzoyl-DL-arginine-2-napthylamide). The guanine-plus-cytosine contents of the deoxyribonucleic acids of group A strains ranged from 48 to 51 mol\%; group E strain guanine-plus-cytosine contents ranged from 44 to 47 mol\%. The members of groups B, C, and D (12 strains) all fluoresced and were indole positive. Group D strains hemagglutinated sheep erythrocytes, whereas groups B and C strains did not. Trypsin-like activity occurred in groups $\mathrm{C}$ and $\mathrm{D}$ but not in group $\mathrm{B}$, and all strains produced phenylacetic acid (group B average, $11 \mu \mathrm{g} / \mathrm{ml}$; group C average, $313 \mu \mathrm{g} / \mathrm{ml}$; group D average, $999 \mu \mathrm{g} / \mathrm{ml}$ ). The group B, C, and D, deoxyribonucleic acids had the following guanine-plus-cytosine contents: group B, 45 to $47 \mathrm{~mol} \%$; group C, 45 to $48 \mathrm{~mol} \%$; group D, 49 to $50 \mathrm{~mol} \%$. All groups of strains differed phenotypically and by isoelectric focusing of bacterial proteins from the asaccharolytic pigmented type strains Bacteroides gingivalis ATCC 33277 and Bacteroides asaccharolyticus ATCC 25260; they were different also from the saccharolytic pigmented type strains Bacteroides levii ATCC 29147, Bacteroides intermedius ATCC 25611, and Bacteroides macacae ATCC 33141.
\end{abstract}

Black- or brown-pigmented Bacteroides species are commonly isolated from human mouths, intestines, and genitalia as part of the normal flora of these regions. Similar organisms have been described less frequently from oral and nonoral sites in other animals, including monkeys and dogs. These organisms are thought also to have pathogenic roles in diseases at or adjacent to sites where they reside as part of the normal flora. In these situations they are present most frequently as part of mixed anaerobic infections (3).

Both saccharolytic and asaccharolytic pigmented Bacteroides strains exist at both oral and nonoral sites. The taxonomic position of these organisms and descriptions of new and existing species, especially species containing asaccharolytic strains, have received considerable attention in recent years $(2,4,5,7,8,10,18-20,22,23)$. It was the opinion of Coykendall et al. (2) that many genotypes of asaccharolytic organisms exist, each with a preferred host. This opinion is borne out when close attention is given to the many isolates described in major publications $(2,6,19,22$, 23).

During a study of the organisms isolated from soft-tissue infections in cats $(11,14)$, we isolated a number of strains of black- or brown-pigmented asaccharolytic Bacteroides. In our opinion these isolates have a common origin (mouths of cats), and they formed a large proportion of the organisms present in the purulent material examined.

\section{MATERIALS AND METHODS}

The bacterial strains studied were isolated from cats, each with either a solitary fight wound abscess or pyothorax. The organisms were part of a mixed flora of anaerobic and facultatively anaerobic bacteria found in these lesions. These strains were selected from 29 asaccharolytic pigmented Bacteroides strains which have been described in some

\footnotetext{
* Corresponding author.
}

detail previously and were identified as Bacteroides asaccharolyticus (13). Cultures of each strain were freeze-dried in skim milk after preliminary characterization; subsequently, the cultures were revived and then fully characterized in parallel. The following strains were obtained from the American Type Culture Collection: Bacteroides gingivalis ATCC $33277^{\mathrm{T}}$ (T-type strain), Bacteroides intermedius ATCC $25611^{\mathrm{T}}$, Bacteroides levii ATCC $29147^{\mathrm{T}}$, Bacteroides asaccharolyticus ATCC $25260^{\mathrm{T}}$, and Bacteroides macacae ATCC $33141^{\mathrm{T}}$.

Methods of characterization. The organisms were grown on plates containing $50 \mathrm{ml}$ of sheep blood agar (Oxoid blood agar base no. 2) per liter supplemented with $10 \mathrm{~g}$ of glucose per liter and vitamin K-hemin (5). All of the media used for subsequent tests and for deoxyribonucleic acid (DNA) extraction contained vitamin K-hemin. The plates were manipulated under oxygen-free carbon dioxide, and prereduced media were handled by using an anaerobic work bench (Bellco Glass, Inc., Vineland, N.J.). The basal media used for fermentation studies were the media described by Holdeman et al. (5). Fermentation of carbohydrates was determined by measuring the $\mathrm{pH}$ of a culture containing a carbohydrate after 5 days and comparing it with the $\mathrm{pH}$ of the basal medium without carbohydrate incubated for the same length of time. Organisms were considered weakly positive if a drop of $0.3 \mathrm{pH}$ unit was recorded and positive if a drop of $>0.5 \mathrm{pH}$ unit occurred. The biochemical tests were performed either in Anaerobic System jars (Oxoid Ltd., London, England) or in prereduced media. The reagents and methods used for examining nitrate reduction, esculin hydrolysis, production of indole from cooked meat medium (12) (tested 2, 7, and 14 days), growth in bile salts (20 g of Difco oxgall per liter), gelatin liquefaction, and starch hydrolysis have been described previously, as has the method used for analysis of fatty acids by gas-liquid chromatography from cooked meat medium, cooked meat-carbohydrate, pep- 
tone-yeast extract broth, peptone-yeast extract broth containing threonine, peptone-yeast extract broth containing pyruvate, and peptone-yeast extract broth containing lactate $(12,13)$ after 5 days of incubation. Phenylacetic acid was detected in methylated samples as described by Assche (1). Colonial color development was noted, and color and duration of colonial fluorescence were recorded at 24 and $48 \mathrm{~h}$ and again after 7 and 14 days by using an ultraviolet light source at $365 \mathrm{~nm}$, as described by Shah et al. (17). Hemagglutination activity was determined by the slide test (18), using $3 \%$ sheep erythrocytes; trypsin-like activity was determined by using $N$-benzoyl-DL-arginine-2-naphthylamide, and $\alpha$-glucosidase activity was determined by using $p$ nitrophenyl- $\alpha$-glucoside, as described by Laughton et al. (9). Catalase production was determined by adding a few drops of $3 \% \mathrm{H}_{2} \mathrm{O}_{2}$ to organisms which had been removed by centrifugation from prereduced brain heart infusion broth (Oxoid) containing vitamin $\mathrm{K}$-hemin (5). The reaction was compared with the reaction in basal medium, as well as with the reaction in cultures which had been treated similarly after heating to $60^{\circ} \mathrm{C}$ for $10 \mathrm{~min}$ and after $5 \mathrm{~min}$ of exposure to $0.001 \mathrm{M}$ (final concentration) potassium cyanide (19). The requirement for vitamin K-hemin was checked by attempting to grow the organisms in brain heart infusion broth alone. Resistance to antimicrobial agents was detected by using the broth disk method (24). The organisms used for extraction of DNA were grown for 24 or $48 \mathrm{~h}$ in $80-\mathrm{ml}$ amounts of brain heart infusion broth containing vitamin $\mathrm{K}$-hemin.

DNA was extracted essentially as described by Marmur (15), and the guanine-plus-cytosine $(G+C)$ contents of the DNA preparations were determined by the thermal melting point method (16). DNA from Escherichia coli $(\mathrm{G}+\mathrm{C}$ content, 50 to $52 \mathrm{~mol} \%$; Sigma Chemical Co., St. Louis, Mo.) was included as a control in each thermal melting point procedure. At least two separate DNA preparations were made for all organisms, and $\mathrm{G}+\mathrm{C}$ ratio estimations were made at least twice on each preparation.

The organisms used for crude protein analyses were grown for $24 \mathrm{~h}$ in $40-\mathrm{ml}$ quantities of brain heart infusion broth containing vitamin $\mathrm{K}$-hemin. The organisms were harvested by centrifugation at $20,000 \times g$ for $10 \mathrm{~min}$, the pellets were drained completely of supernatant, and the cells were weighed. The pelleted organisms were suspended in a quantity of distilled water equal to the wet weight of the cells. Each cell suspension was sonicated at $4^{\circ} \mathrm{C}$ in a Cup Horn by using continuous sonication at the full power output for 30 min (model 375 sonicator; Heat Systems Ultrasonics, Inc.). After sonication, the preparation was centrifuged at $20,000 \times g$ for $30 \mathrm{~min}$, and the supernatant was stored at $-20^{\circ} \mathrm{C}$ until it was used.

For isoelectric focusing studies, a model 211-301 Multiphor apparatus (LKB Instruments Inc., Rockville, Md.) was used in conjuction with an LKB model 2103DC power supply. The Isogel agarose isoelectric focusing technique (FMC Corp., Marine Colloids Div., Rockland, Maine) was used to prepare and process 1-mm-thick gels. Paper electrofocusing strips (type 2117-106; LKB) were soaked in $1 \mathrm{M}$ $\mathrm{H}_{3} \mathrm{PO}_{4}$ for the anode and in $1 \mathrm{M} \mathrm{NaOH}$ for the cathode and drained of excess solution before careful positioning on the gel surface. A Braun Thermomix II apparatus was used to circulate melting ice water through the cooling plate at the rate of 21 liters/min to control the temperature during the run. Bacterial extracts $(5 \mu \mathrm{l}$ each) were placed into the template slits on the surface of the gel. Samples were run on the plates at $10 \mathrm{~mA}$ for $20 \mathrm{~min}$. The template was removed, and the samples were run for an additional $30 \mathrm{~min}$ at $25 \mathrm{~W}$.
The final voltage was stable at $1,020 \mathrm{~V}$. At the conclusion of the run the gel was treated as described in the Isogel technique notes by using Kenacid Blue R (catalog no. 4424S; $\mathrm{BDH}$, Poole, England) as the protein stain.

\section{RESULTS AND DISCUSSION}

Morphology and growth characteristics. All strains were obligately anaerobic, gram-negative, nonmotile, nonsporeforming, rod-shaped or coccoid organisms which required or were stimulated by vitamin K-hemin. After incubation on blood agar plates, colonies were 0.5 to $1 \mathrm{~mm}$ in diameter, circular, convex, opaque, and grey or cream after $48 \mathrm{~h}$. After 3 to 5 days the animal strain colonies were greenish brown or black.

The type strains conformed to the descriptions published previously, except that in our hands the $\mathrm{G}+\mathrm{C}$ content of $B$. asaccharolyticus ATCC $25260^{\mathrm{T}}$ DNA was 47 to $48 \mathrm{~mol} \%$ (previously published value 51 to $54 \mathrm{~mol} \%$ ) and $B$. macacae ATCC $33141^{\mathrm{T}}$ hemagglutinated sheep erythrocytes. All of the cat strains, B. gingivalis ATCC $33277^{\mathrm{I}}$, and B. asaccharolyticus ATCC $25260^{\mathrm{T}}$ failed to ferment carbohydrates, whereas B. levii ATCC $29147^{\mathrm{T}}, B$. intermedius ATCC $25611^{\mathrm{T}}$ and $B$. macascae ATCC $33141^{\mathrm{T}}$ fermented carbohydrates, as described elsewhere $(2,6)$. These strains were susceptible to all of the antimicrobial agents tested. All cat strains and type strains were subjected to a series of biochemical and other tests that are considered helpful in differentiating brown- and black-pigmented Bacteroides species. Table 1 shows the reactions of the cat strains in this group of tests and compares these reactions with the reactions of the type strains studied. All asaccharolytic cat strains were catalase positive, indole positive, did not produce $\alpha$-glucosidase, and did not grow in bile salts. The catalase test alone divided these strains from the human strains. The cat strains produced acetic, propionic, isobutyric, butyric, and isovaleric acids from cooked meat medium or cooked meat-carbohydrate or both, although individual strains varied in the amounts of these acids produced.

As Fig. 1 shows, all of the type strains had distinctive band patterns, although many proteins banded at the same $\mathrm{pH}$ values. Similar band patterns occurred even with asaccharolytic and saccharolytic species. Likewise, the cat strains could be divided into five groups based on band patterns, which correlated with groupings based on other phenotypic characteristics (Table 1). One group (group A) had a pattern similar to that of $B$. gingivalis ATCC $33277^{\mathrm{T}}$, whereas group B had a pattern similar to that of $B$. asaccharolyticus ATCC $25260^{\mathrm{T}}$. The other groups had patterns which differed markedly from each other and from the type strains studied.

Both groups A and group B strains were catalase positive. This was the only major difference between group A organisms and $B$. gingivalis ATCC $33277^{\mathrm{T}}$. In addition, group B organisms produced phenylacetic acid (average, $11 \mu \mathrm{g} / \mathrm{ml}$ ), which $B$. as accharolyticus ATCC $25260^{\mathrm{T}}$ and other B. asaccharolyticus strains are considered unable to do $(2,7)$. Also, group B organisms (Table 1) had $\mathrm{G}+\mathrm{C}$ contents of 45 to 47 mol\%.

Despite the similarity of band patterns, it is unlikely that our cat strains conform to any species described to date. The patterns of groups A, B, C, D, and E do not resemble each other or the patterns of type strains; each of these groups probably represents a different species. DNA homology studies (which we are unable to undertake) will be required to determine the relatedness of these groups to each other and to the type strains.

A small number of catalase-positive dog strains, which 
TABLE 1. Characteristics of groups of pigmented asaccharolytic Bacteroides strains isolated from soft-tissue infections of cats and human asaccharolytic type strains

\begin{tabular}{|c|c|c|c|c|c|c|c|c|}
\hline Group or strain & $\begin{array}{l}\text { No. of } \\
\text { strains }\end{array}$ & $\begin{array}{l}\text { Colony pig- } \\
\text { ment }(\mathrm{s})\end{array}$ & $\begin{array}{l}\text { Fluores- } \\
\text { cence }\end{array}$ & Catalase & $\begin{array}{l}\text { Hemag- } \\
\text { glutina- } \\
\text { tion }\end{array}$ & $\begin{array}{l}\text { Trypsin- } \\
\text { like ac- } \\
\text { tivity }\end{array}$ & $\begin{array}{l}\text { Phenyl- } \\
\text { acetic } \\
\text { acid( }(\mu \mathrm{g} / \\
\mathrm{ml})^{a}\end{array}$ & $\begin{array}{l}\mathrm{G}+\mathrm{C} \text { con- } \\
\text { tent }(\mathrm{mol} \%)\end{array}$ \\
\hline $\mathbf{A}$ & 3 & Brown,black & - & + & + & + & 497 & $48-51$ \\
\hline B & 3 & Green,black & + & + & - & - & 11 & $45-47$ \\
\hline $\mathrm{C}$ & 7 & Green,black & + & + & - & + & 313 & $45-48$ \\
\hline $\mathrm{D}$ & 2 & Black & + & + & + & + & 999 & $49-50$ \\
\hline $\mathrm{E}$ & 2 & Gray,brown & - & + & - & + & 404 & $44-47$ \\
\hline $\begin{array}{l}\text { B. gingivalis } \\
\text { ATCC } 33277^{\mathrm{T}}\end{array}$ & & Brown,black & - & - & + & + & 1.6 & $48-50$ \\
\hline $\begin{array}{l}\text { B. asaccharolyticus } \\
\text { ATCC } 25260^{\mathrm{T}}\end{array}$ & & Black & + & - & - & - & 0 & $47-48$ \\
\hline
\end{tabular}

${ }^{a}$ Average production by strains tested after 5 days of incubations at $37^{\circ} \mathrm{C}$.

physiologically resemble $B$. asaccharolyticus, have been described as having $\mathrm{G}+\mathrm{C}$ contents of 41 to $43 \mathrm{~mol} \%(7)$, and Laughton et al. (9) also mentioned beagle dog strains which may or may not have trypsin-like activity and may or may not have $\alpha$-glucosidase. However, in all of these instances, the descriptions of the biochemical parameters of the asaccharolytic pigmented Bacteroides strains from nonprimate sources are incomplete. The recent publication of Laliberté and Mayrand (8), who described 50 isolates from 15 cats, is also incomplete in its description of biochemical parameters. These authors did not mention whether their strains fluoresced and did not give the DNA $G+C$ contents of their strains; all of the cat and dog strains mentioned by them hemagglutinated erythrocytes, had trypsin-like activity, and produced phenylacetic acid. In these ways these strains were similar to our group A and D cat strains. Also, as the cat strains are all strict anaerobes which die rapidly when exposed to air, it is unlikely that they are members of the $B$. asaccharolyticus toxon isolated from dogs and described by Syed (21).

Only our group A and E cat strains failed to fluoresce after
24 to $48 \mathrm{~h}$. Group A organisms resembled B. gingivalis (which failed to fluoresce also), but group $E$ organisms differed in several reactions (Table 1). Therefore, the use of the fluorescence test in this ecological niche may not be as useful as it is in human studies (20) since the members of all of the other groups (only one of which resembled B. asaccharolyticus) fluoresced. Also, the hemagglutination test is less useful for cat strain differentiation than for differentiation of human $B$. gingivalis and $B$. asaccharolyticus (18). The same difficulty was experienced in the use of strain reactions to trypsin-like activity and $\alpha$-glucosidase activity. Laughton et al. $(9,10)$, found that these test combinations are useful for differentiating $B$. gingivalis from $B$. asaccharolyticus. However, group A, C, D, and E cat strains (Table 1) all showed trypsin-like activity and did not produce $\alpha$ glucosidase (i.e., they were identical to $B$. gingivalis). Despite these difficulties, it is possible to group the cat strains by using the more extensive combination of biochemical tests listed in Table 1. For practical diagnostic laboratories, this combination does not include the need for isoelectric focusing or DNA base ratio estimations (Table 1).

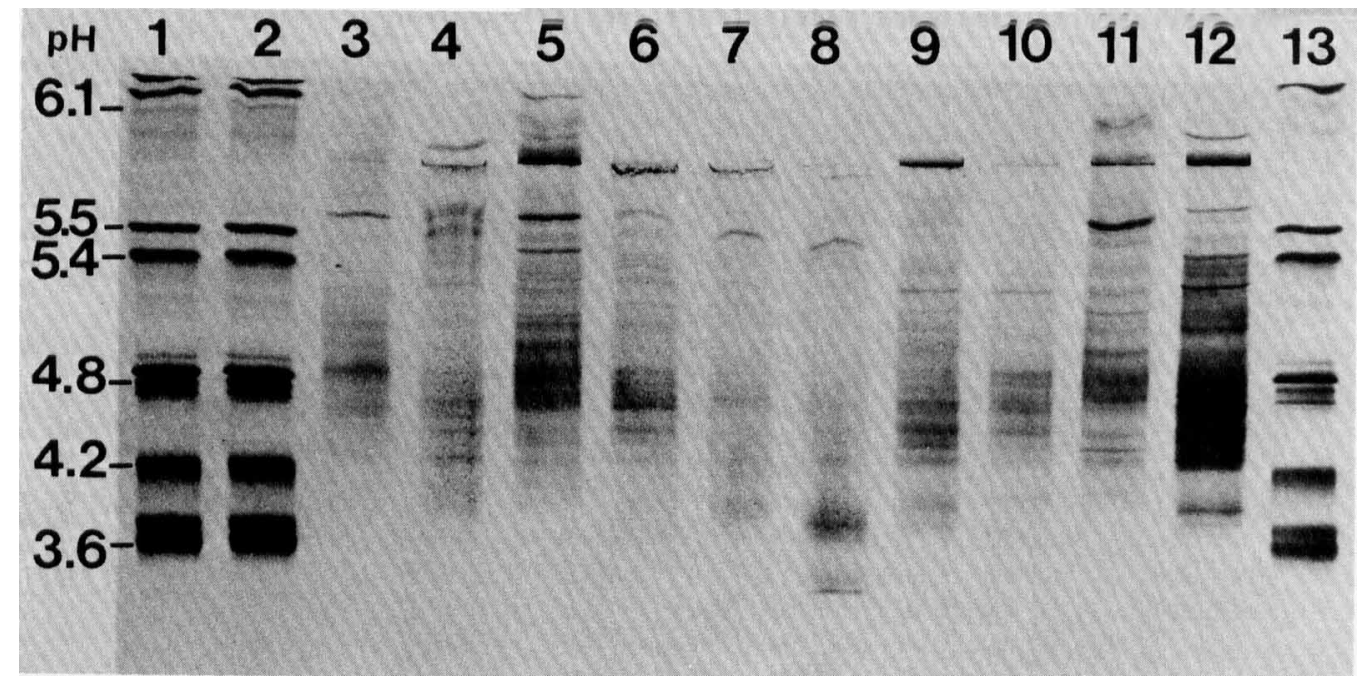

FIG. 1. Isoelectric tocusing agarose gel patterns of type strains and groups of asaccharolytic Bacteroides strains isolated from cats. Lanes 1, 2, and 13, Isogel pI markers (with pH values indicated); lane 3, group E cat strains; lane 4, group D cat strains; lane 5, group C cat strains; lane 6, group B cat strains; lane 7, group A cat strains; lane 8, B. gingivalis ATCC $33277^{\mathrm{T}}$; lane 9, B. asaccharolyticus ATCC $25260^{\mathrm{T}}$; lane 10 , B. intermedius ATCC $25611^{\mathrm{T}}$; lane $11, B$, macacae ATCC $33141^{\mathrm{T}}$; lane $12, B$. levii ATCC $29147^{\mathrm{T}}$. 


\section{ACKNOWLEDGMENTS}

We gratefully acknowledge the skilled technical assistance of G. Tsoukalas and C. Wilcox, who prepared all of the media, and I. Weston for photography.

This research was supported by the Australian Research Grants Scheme.

\section{LITERATURE CITED}

1. Assche, P. F. D. 1978. Differentiation of Bacteroides fragilis species by gas chromatographic detection of phenylacetic acid. J. Clin. Microbiol. 8:614-615.

2. Coykendall, A. L., F. S. Kaczmarek, and J. Slots. 1980. Genetic heterugeneity in Bacteroides asaccharolyticus (Holdeman and Moore 1970) Finegold and Barnes 1977 (Approved Lists, 1980) and proposal of Bacteroides gingivalis sp. nov. and Bacteroides macacae (Slots and Genco) comb. nov. Int. J. Syst. Bacteriol. 30:559-564.

3. Finegold, S. M. 1977. Anaerobic bacteria in human disease. Academic Press, Inc., New York.

4. Finegold, S. M., and E. M. Barnes. 1977. Report of the ICBS Taxonomic Subcommittee on Gram-Negative Anaerobic Rods. Int. J. Syst. Bacteriol. 21:388-394.

5. Holdeman, L. V., E. P. Cato, and W. E. C. Moore. 1977. Anaerobic Jaboratory manual, 4th ed. Virginia Polytechnic Institute and State University, Blacksburg.

6. Johnson, J. L., and L. V. Holdeman. 1983. Bacteroides intermedius comb. nov. and descriptions of Bacteroides corporis sp. nov. and Bacteroides levii sp. nov. Int. J. Syst. Bacteriol. 33:288-290.

7. Kaczmarek, F. S., and A. L. Coykendall. 1980. Production of phenylacetic acid by strains of Bacteroides asaccharolyticus and Bacteroides gingivalis (sp. nov.). J. Clin. Microbiol. $12: 288-290$.

8. Laliberté, M., and D. Mayrand. 1983. Characterisation of blackpigmented Bacteroides strains isolated from animals. J. Appl, Bacteriol. 55:247-252.

9. Laughton, B. E., S. A. Syed, and W. J. Loesche. 1982. API ZYM system for identification of Bacteroides spp., Capnocytophaga spp., and spirochetes of oral origin. J. Clin. Microbiol. 15:97102 .

10. Laughton, B. E., S. A. Syed, and W. J. Loesche. 1982. Rapid identification of Bacteroides gingivalis. J. Clin. Microbiol.
15:345-346.

11. Love, D. N., R. F. Jones, and M. Bailey. 1979. Isolation and characterisation of bacteria from abscesses in the subcutis of cats. J. Med. Microbiol. 12:207-212.

12. Love, D. N., R. F. Jones, and M. Bailey. 1979. Clostridium villosum $\mathrm{sp}$. nov. from subcutaneous abscesses in cats. Int. J. Syst. Bacteriol. 29:241-248.

13. Love, D. N., R. F. Jones, and M. Bailey. 1981. Characterisation of Bacteroides species isolated from soft tissue infections in cats. J. Appl. Bacteriol. 50:567-575.

14. Love, D. N., R. F. Jones, N. Bailey, R. S. Johnson, and N. Gamble. 1982. Isolation and characterisation of bacteria from pyothorax (Empyaemia) in cats. Vet. Microbiol. 7:455-461.

15. Marmur, J. 1961. A procedure of the isolation of deoxyribonucleic acid from microorganisms. J. Mol. Biol. 3:208-218.

16. Marmur, J., and P. Doty. 1962. Determination of the base composition of deoxyribonucleic acid from its thermal denaturation temperature. J. Mol. Biol. 5:109-118.

17. Shah, H. M., R. Bonnett, B. Mateen, and R. A. D. Williams. 1979. The porphyrin pigmentation of subspecies of Bacteroides melaninogenicus. Biochem. J. 180:45-50.

18. Slots, J., and R. J. Genco. 1979. Direct hemagglutination technique for differentiating Bacteroides asaccharolyticus oral strains from nonoral strains. J. Clin. Microbiol. 10:371-373.

19. Slots, J., and R. J. Genco. 1980. Bacteroides melaninogenicus subsp. macacae, a new subspecies from monkey periodontopathic indigenous microflora. Int. J. Syst. Bacteriol. 30:82-85.

20. Slots, J., and H. S. Reynolds. 1982. Long-wave UV light fluorescence for identification of black-pigmented Bacteroides spp. J. Clin. Microbiol. 16:1148-1151.

21. Syed, A. S. 1980. Characteristics of Bacteroides asaccharolyticus from dental plaques of beagel dogs. J. Clin. Microbiol. 11:522-526.

22. Van Steenbergen, T. J. M., C. A. Vlaanderen, and J. de Graaff. 1981. Confirmation of Bacteroides gingivalis as a species distinct from Bacteroides asaccharolyticus. Int. J. Syst. Bacteriol. 31:236-241.

23. Watabe, J., Y. Benno, and T. Mitsouka. 1983. Taxonomic study of Bacteroides oralis and related organisms and proposal of Bacteroides veroralis sp. nov. Int. J. Syst. Bacteriol. 33:57-64.

24. Wilkins, T. D., and T. Thiel. 1973. Modified broth-disk method for testing the antibiotic susceptibility of anaerobic bacteria. Antimicrob. Agents Chemother. 3:350-356. 